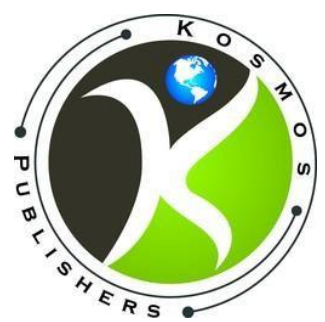

www.kosmospublishers.com

contact@kosmospublishers.com

DOI: 10.37722/AAHAE.202042

Research Article

Advances in Agriculture, Horticulture and Entomology

ISSN 2690-1900

\title{
Results of Testing the Leaching Ability of the Biosolvent Preparation on Salted Soils of the Middle Current of the Syrdarya River
}

\author{
Yulia Shirokova $^{1 *}$, Gauharay Paluashova ${ }^{2}$, Farhod Sadiev $^{3}$ \\ ${ }^{1}$ Agricultural Sciences, Senior Researcher. Scientific Research Institute of Irrigation and Water Problems \\ (SRIIWP), Tashkent, Uzbekistan \\ ${ }^{2}$ Technical Sciences. Scientific Research Institute of Irrigation and Water Problems (SRIIWP), Tashkent, \\ Uzbekistan \\ ${ }^{3}$ Scientific Research Institute of Irrigation and Water Problems (SRIIWP), Tashkent, Uzbekistan
}

Received Date: August 20, 2020; Accepted Date: August 26, 2020; Published Date: September 03, 2020

*Corresponding author: Yulia Shirokova, candidate of agricultural Sciences, Scientific Research Institute of Irrigation and Water Problems (SRIIWP), Tashkent, 100187, Tashkent city, Karasu district-4/11. Uzbekistan. Tel: +998901682751;

Email: yulia.i.shirokova@gmail.com

\section{Abstract}

On the irrigated saline soils of the Syrdarya region of Uzbekistan, the leaching capacity of the Biosolvent desalination device has been studied. The experiments were carried out on bulk soil columns, as well as in the field: during the period of land leaching and irrigation of cotton. Field experiments and phenological observations of plants were carried out according to generally accepted methods. Soil analysis methods follow: texture, - by method of sedimentation; salinity - by measurement of electrical conductivity, in the soil- water suspension (1:1); ionic composition, - by method titration and gravimetric in a soil water extract 1:5. When leaching the soils on the columns with a $2 \%$ solution of the preparation, as well as when spraying the soil with a $10 \%$ solution of it, before pouring water, the leaching of $\mathrm{HCO}_{3} \mathrm{Ca}$ and $\mathrm{Mg}$ ions increases most of all. By field experiments on soil leaching, with preliminary treatment of the surface inside of the checks with the preparation in a ratio of $1: 10$, the efficiency of salt leaching increased by $35 \ldots 42 \%$. This will save $2000 \mathrm{~m} 3$ / ha of water, with a drug consumption of 10 1/ha. Testing a preparation for treating the surface of furrows before watering cotton to reduce salt stress on plants showed an increase in salt leaching by $18-23 \%$. As a result of improved conditions in the root zone of cotton, an increase in yield of $7.5 \mathrm{c} /$ ha was obtained. The use of this preparat to reduce seasonal soil salinization in the fields is available to farmers.
Keywords: Cotton Harvest; Furrow Irrigation; Increased Salt Leaching; Saline Soils; Soil Conditioner Biosolvent

\section{Introduction}

In connection with the importance of sustainable agricultural production, which ensures food security of the population of countries, their economic and political stability, the issue of increasing soil productivity, including land reclamation, is very important. Soil degradation brings great economic losses and threats to humanity. Different countries experience different forms of soil degradation, which determine the types of land reclamation. In an arid climate on irrigated lands, salinization spreads, often caused by closely located mineralized ground waters.

According to the Ministry of Water Resources of the Republic as of 01.01.2019, the area of saline lands is about 2 million hectares, or $45 \%$ of the irrigated land, and the areas with medium and strong salinity, respectively, $12 \%$ and $2 \%$ of the irrigated area. On the territory of the Syrdarya region of Uzbekistan, called the Hungry Steppe, there is still a problem of insufficient land productivity, the main reason for which is soil salinization. Salinization of irrigated lands in the Syrdarya region is spread over $90 \%$ of the irrigated area, more than $20 \%$ of which are lands of medium and strong salinity. The reasons 
for the spread of salinization in this zone are both genetic (natural) salinization of lands and anthropogenic impacts.

The source of secondary (seasonal) soil salinization in the aeration zone is groundwater, which is mainly located at a depth of about $2.0 \mathrm{~m}$ from the surface and has a salinity of 4-5 g/l. Groundwater replenishment occurs primarily due to the loss of irrigation water associated with both the lack of anti- filtration measures on the transporting part of the irrigation network, and with water distribution and water use dispersed over the area. In some territories, there are drawbacks of water disposal (drainage), and in the fields, imperfect irrigation technologies are mainly used, with unsatisfactory leveling off the field surface. According to the chemical composition of salts, in this zone salinity is generally considered neutral and is represented by poorly soluble compounds $\mathrm{CaSO}_{4}, \mathrm{Ca}\left(\mathrm{HCO}_{3}\right)_{2}$, as well as soluble (toxic) salts: $\mathrm{NaCl}, \mathrm{Na}_{2} \mathrm{SO}_{4}, \mathrm{MgSO}_{4}, \mathrm{MgCl}_{2}$. Soil $\mathrm{pH}$ generally does not exceed 8,3 .

The most effective known method of combating salinization of irrigated soils is leaching them against the backdrop of wellfunctioning drainage.

In the past, when developing highly saline and compacted lands, they used capital leaching with water supply up to 30 thousand $\mathrm{m} 3$ / ha. At the same time, to accelerate and improve the leaching of the salts from soil (reduction of water supply rates), was used: deep loosening of the soil (up to $1 \mathrm{~m}$ ), with the addition of large doses of manure or lignin (up to $40 \mathrm{t} / \mathrm{ha}$ ) or dry crushed cotton stalks; strengthening of permanent drainage, - temporary open drains; adding chemicals to the soil (complex polymer fertilizers), etc.

Currently, many of these measures, such as large volumes of water, temporary drainage, large doses of organic fertilizers and additives, are not available. Therefore, farmers mainly carry out winter-spring leaching of land by checks, with water supply: for moderately saline lands $4000-5000 \mathrm{~m} 3 / \mathrm{ha}$, and for highly saline lands - more than $6000 \mathrm{~m} 3$ / ha. With a shortage of water resources, sometimes even such volumes of water are problematic to supply, the more drainage should work perfectly. In practice, farmers do not always manage to achieve the desired limits of soil desalinization. In this regard, in order to save water and get the harvest, it is relevant to search for means that increase the efficiency of land leaching [1].

The problems of the influence of salinization of lands on their productivity and the principles of managing the water-salt regime, considered in a number of foreign publications [2-5], showed that the issues of improving technology and increasing the efficiency of leaching, or new technology combating soil salinity, are not sufficiently reflected in published works, therefore, cannot be used in Uzbekistan.

Studies the authors' on the effectiveness of leaching, carried out in the conditions of Uzbekistan [6], found that, even with high volume of water supply for leaching and ensured drainage of water (drainage), complete release of the soil from salts not occur.

One of the options for increasing the efficiency of salt leaching is the use of special desalination preparations. In the modern world, various types of preparations has been developed to improve the properties of saline soils (J.G. Davisand, D. Whiting, 2005) [5]. Salt correctors with polymaleic acid, such as SperSal 35, Stop-Sal, NON SAL, recommended among the preparations for saline soils [7-9]. According to manufacturers and distributors, these preparations: accelerate the leaching of salts, increase the efficiency of irrigation; increase the productivity of crops by extracting nutrients from the soil. They are easy to use, environmentally friendly and biodegradable [9].

The solution for increasing the efficiency of leaching salts from soil could be the use of an analogue of the foreign preparation "Spersal", the preparation Biosolvent (authors Khudoynazarov I., Turaev A. - Institute of Bioorganic Chemistry of the Academy of Sciences of Uzbekistan [10]). However, for the confident application of local preparation, reliable experimental verification was necessary.

This article discusses the results of the studies of authors' on testing the Biosolvent preparation as an enhancer of the leaching of salts from the soil in laboratory conditions on bulk columns, growing vessels and in field experiments, in the period from 2015 to 2017. Some fragments of these studies were reflected in the publications of the authors [10-14].

\section{Materials and Methods}

The test plots are located in the Mirzaabad district of the Syrdarya region (Figure 1). For laboratory experiments in bulk columns and for growing vessels, the soil was delivered from the same territory.

According to the general survey of the site, the texture of the soil is homogeneous, light loamy with rare interlayers of sandy loam. Salinization of soils of the site (average in the layer 0-100) at individual points is in the range from 4 to $18 \mathrm{dS} / \mathrm{m}$ (Table 1). 


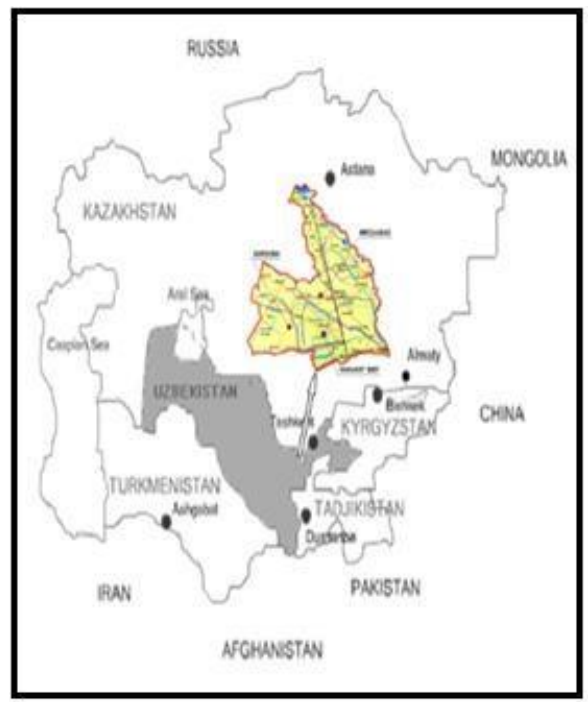

Figure 1: Location of the Syrdarya region on the territory of Uzbekistan and the location of experimental sites.

\begin{tabular}{|c|c|c|c|}
\hline \multirow{3}{*}{ Soil salinity } & \multicolumn{3}{|c|}{ Evaluation criteria } \\
\hline & \multirow{2}{*}{$\begin{array}{c}\text { FAO } \\
\text { ECe, dS/m }\end{array}$} & \multicolumn{2}{|c|}{$\begin{array}{l}\text { Local, by content } \\
\end{array}$} \\
\hline & & Cl', \%* & $\mathrm{Na}^{\prime}$, me / $100 \mathrm{~g}$ of soil ** \\
\hline Not salted & $0-2$ & $<0,02$ & $<1$ \\
\hline Slightly salted & $2-4$ & $0,02-0,035$ & $1,0-3,0$ \\
\hline Medium saline & $4-8$ & $0,035-0,07$ & $3,1-6,0$ \\
\hline Highly salted & $8-16$ & $0,07-0,14$ & $6,1-12,0$ \\
\hline Very highly salted & $>16$ & $>0,14$ & $12,1-28,0$ \\
\hline
\end{tabular}

Table 1: Classifications for assessing the degree of soil salinity.

Experimental study of the leaching capacity of Biosolvent and the search for technologies for its use were carried out in four stages (Table 2).

\begin{tabular}{|c|c|c|}
\hline No. & Description of experiments & Purpose and comments \\
\hline 1 & $\begin{array}{l}\text { Laboratory experiments on modelling leaching } \\
\text { salt from the soil on bulk columns. Soil } \\
\text { salinity ECe from } 6 \text { to } 10 \mathrm{dS} / \mathrm{m} \text {. Experiment- } 1 \text {. } \\
\text { washing of saline soil with a solution of } \\
\text { Biosolvent with a concentration of } 2 \% \text { and } \\
10 \% \text {, in a volume of } 1000 \mathrm{~m} 3 / \mathrm{ha}, \mathrm{ECe}=6.92 \\
\mathrm{dS} / \mathrm{m} \text {. Control }- \text { leaching with distilled water } \\
\text { Experiment- } 2, \text { the same, with supply of water } \\
\text { volume of } 500 \mathrm{~m}^{3} / \mathrm{ha} \text {, soil salinity according } \\
\text { to ECe }=9.88 \mathrm{dS} / \mathrm{m} \text {. Concentrations of } \\
\text { solutions } 0.2 \%, 1 \% \text { and } 2 \%\end{array}$ & $\begin{array}{l}\text { The purpose of the experiments is to establish the leaching capacity, the } \\
\text { optimal concentration of the preparation Biosolvent and the technology of } \\
\text { its use during wash of soil. The soil for filling the columns was dried, } \\
\text { crushed, sieved through a } 2 \mathrm{~mm} \text { sieve and thoroughly mixed. The columns } \\
\text { were installed on a container to collect the filtrate. The bottom of the } \\
\text { column was covered with a special mesh, on which a filter was placed ( } 10 \\
\mathrm{~cm} \text { layer). The large columns used a two-layer gravel pack. The diameter } \\
\text { of the columns of the filled soil in test } 1 \text { is } 15 \mathrm{~cm} \text {, and in test } 2 \text { it is } 25 \mathrm{~cm} \text {, } \\
\text { the thickness of the soil layer is } 15 \text { and } 25 \mathrm{~cm} \text {, respectively. The } \\
\text { experiments were carried out in triplicate. In process of the experiments, } \\
\text { the volume and EC and the chemical composition of the leachate formed } \\
\text { during washing were measured. Chemical and agrochemical analyzes of } \\
\text { the soil were performed before and after leaching. }\end{array}$ \\
\hline 2 & $\begin{array}{l}\text { Experiments on leaching of salt from soil in } \\
\text { vegetation vessels. Supply of Water } 1500 \mathrm{~m}^{3} / \\
\text { ha. Soil salinity according to ECe from } 6 \text { to } 10 \\
\quad \mathrm{dS} / \mathrm{m} \text {. } \\
\text { Variant Control - the usual leaching of the soil } \\
\text { by river water. } \\
\text { Experience - the same, with spraying the soil } \\
\text { surface before leaching with } 9 \% \text { solution of }\end{array}$ & $\begin{array}{l}\text { The purpose of the experiment is to investigate the leaching effect of } \\
\text { Biosolvent (diluted with water } 1: 10 \text { ), with preliminary spraying of the soil } \\
\text { surface immediately before washing saline soils. The experiment was } \\
\text { carried out in vegetative vessels with a diameter of } 25 \mathrm{~cm} \text { and a height of } \\
70 \mathrm{~cm} \text {, with soil preparation similar to the experiments on columns. }\end{array}$ \\
\hline
\end{tabular}




\begin{tabular}{|c|c|c|}
\hline & Biosolvent. & \\
\hline 3 & $\begin{array}{l}\text { Field experiments to study the effect of } \\
\text { Biosolvent during winter-spring leaching of } \\
\text { saline soils. Leaching of saline soil according } \\
\text { to checks sizes } 20 \times 20 \mathrm{~m} \text {, supply of water } 2000 \\
\mathrm{~m}^{3} / \text { ha, soil salinity according to ECe up to } 10 \\
\mathrm{dS} / \mathrm{m} \text {. Control - the usual leaching of the soil } \\
\text { according to checks; Experience - leaching } \\
\text { according to checks, with preliminary soil } \\
\text { treatment (spraying) with Biosolvent diluted } \\
\text { with water } 1: 10 \text {. before filling with water. }\end{array}$ & $\begin{array}{l}\text { The purpose of the experiment is to check in the field: washing ability; } \\
\text { Biosolvent preparation and the technology of its application - by spraying } \\
\text { the soil surface at a concentration (1:10). In the experiment, the soil } \\
\text { salinity (chemical composition) was monitored before and after leaching. } \\
\text { The observations were carried out by points laid down in the leaching } \\
\text { checks diagonally, with soil sampling by horizons of } 0-30,30-70 \text { and } 70- \\
100 \mathrm{~cm} \text {. The supply of water was controlled by Chipoletti spillway. Water } \\
\text { was served separately to each cell (checks). In the variants of the } \\
\text { experiment, soil analyzes were carried out before and after leaching (pH, } \\
\text { EC, TDS; } \mathrm{HCO}_{3} ; \mathrm{Cl} \text { '; } \mathrm{SO}_{4} \text {; } \mathrm{Ca} ; \mathrm{Mg} ; \mathrm{Na} \text { '; } \mathrm{K} \text { '). Statistical processing and } \\
\text { comparison of data between the variants were carried out. }\end{array}$ \\
\hline 4 & $\begin{array}{l}\text { Field experiments on the use of Biosolvent in } \\
\text { furrow irrigation of cotton on saline soils. ECe } \\
\text { from } 5.5 \text { to } 8.6 \mathrm{dS} / \mathrm{m} \text {. } \\
\text { Control - conventional furrow irrigation of } \\
\text { cotton; } \\
\text { Experience - irrigation with preliminary soil } \\
\text { treatment with Biosolvent diluted with water } \\
1: 10 .\end{array}$ & $\begin{array}{l}\text { The purpose of the experiment is to study the possibility of using the } \\
\text { Biosolvent preparation for cotton irrigation to effectively reduce soil } \\
\text { salinity (salt stress of plants) and increase productivity. The surface of the } \\
\text { furrows was treated with a solution of the preparation immediately before } \\
\text { the supply of water for irrigation. Observations of changes in soil salinity, } \\
\text { growth and development of plants were carried out at points on plots } \\
\text { (replicates of experimental variants) located diagonally. Before and after } \\
\text { each irrigation at the control points of the experimental variants, soil } \\
\text { samples were taken for analysis along the horizons: } 0-30,30-70 \text { and } 70- \\
100 \mathrm{~cm} \text {. In soil a sample, the following analyzes were performed: pH, EC, } \\
\text { TDS; HCO3; Cl'; } \mathrm{SO}_{4} \text {; Ca; } \mathrm{Mg} \text {; Na'; K'. All analyzes and phenological } \\
\text { observations were carried out according to generally accepted methods. } \\
\text { Statistical processing and comparison of data between the variants were } \\
\text { carried out. }\end{array}$ \\
\hline
\end{tabular}

Table 2: Experiments with the use of Biosolvent in Mirzaabad district of Syrdarya region.

\section{Results and Discussion}

According to the filtrate data obtained in laboratory experiments on soil washing on columns, Biosolvent solutions of two concentrations showed a higher leaching of salts in comparison with the use of distilled water (Table 3). The
Biosolvent solutions used in the experiments had an acidic medium: at $2 \%$ dilution, the $\mathrm{pH}$ was 2.3 , and $10 \%$, the solution had a $\mathrm{pH}$ of 1.9. In addition, the solutions contained a certain amount of salts: at $2 \%$ dilution $-1.56 \mathrm{~g} / 1$, and at $10 \%-2.68 \mathrm{~g} / \mathrm{l}$ of salts.

\begin{tabular}{|c|c|c|c|c|c|c|c|c|c|c|c|}
\hline \multirow{2}{*}{\multicolumn{2}{|c|}{$\begin{array}{l}\text { Experience Option } \\
\text { filtrate volume, } \mathrm{ml}\end{array}$}} & \multirow{2}{*}{$\underline{\mathrm{pH}}$} & \multirow{2}{*}{$\mathrm{EC}, \mathrm{dS} / \mathrm{m}$} & \multicolumn{8}{|c|}{ Content in g / I } \\
\hline & & & & TDS & $\mathrm{HCO}_{3}^{\prime}$ & $\mathrm{Cl}^{\prime}$ & $\mathrm{SO}_{4}$ & Ca" & Mg* & $\mathbf{N a}^{\prime}$ & $\mathbf{K}^{-}$ \\
\hline \multicolumn{2}{|c|}{$\frac{\text { Control }}{\underline{264}}$} & 7,2 & 6,3 & 5,76 & 0,08 & 0,88 & 4,68 & 0,42 & 0,77 & 0,48 & 0,03 \\
\hline \multicolumn{2}{|c|}{$\frac{\mathrm{P}-1(2 \%)}{280^{*}}$} & 7,1 & 7,5 & 7,74 & 1,33 & 0,80 & 4,04 & 1,20 & 1,24 & 0,53 & 0,04 \\
\hline \multicolumn{2}{|c|}{$\frac{\mathrm{P}-2(10 \%)}{\underline{256^{* *}}}$} & 6,2 & 10,5 & $\begin{array}{c}23,4 \\
3 \\
\end{array}$ & 0,32 & 1,23 & 2,19 & 6,43 & 1,84 & 0,54 & 0,05 \\
\hline \multirow{2}{*}{$\begin{array}{l}\text { Experiment } / \mathrm{c} \\
\text { ontrol ratio }\end{array}$} & $\underline{\mathrm{P}-1}$ & 1,0 & 1,2 & 1,3 & 16,6 & 0,9 & 0,9 & 2,9 & 1,6 & 1,1 & 1,3 \\
\hline & $\underline{\mathrm{P}-2}$ & 0,9 & 1,7 & 4,1 & 4,0 & 1,4 & 0,5 & 15,3 & 2,4 & 1,1 & 1,7 \\
\hline \multicolumn{12}{|c|}{ Substance from the preparation * $-2.8 \mathrm{~g} / \mathrm{l} ; * * 19.8 \mathrm{~g} / \mathrm{l}$} \\
\hline
\end{tabular}

Table 3: The effect of different drug concentrations on the chemical composition of the filtrates (average data from three replicates).

It can be seen from the results that at a drug concentration of $10 \%$ (which used in the form of a solution for soil washing), drained filtrate solution had an acidic medium (6.2), and at $2 \%$ it almost did not differ from the control. According to the EC 
indicator, the removal of salts by the filtrate, at a concentration of Biosolvent of $2 \%$, is on $20 \%$ higher than in the control, and when using a $10 \%$ solution - on $70 \%$.

The greatest effect of the drug on the chemical composition of the filtrate manifested itself in calcium. At a preparation concentration of $2 \%$, the filtrate removed almost 3 times more calcium from the soil (and at 10\% concentration, 15 times more) than in the control. For magnesium and TDS, these figures were respectively: $\mathrm{Mg}$ in 1.6; 2.4 times more, and the TDS, - in 1.3 and 4.1 times. On the contrary, the content of sulfates in the filtrates when using Biosolvent decreased: at a drug concentration of $2 \%$, the filtrate removed sulfates by 10 , and at $10 \%$ concentration - by $50 \%$, less than in the control variant (Table 3). The preparation had the least effect on the sodium content in the filtrates: it is almost does not differ from the control.

According to laboratory experiments on columns, it was concluded that, for soils with a medium degree of salinity, $10 \%$ concentration of the Biosolvent preparation is the most effective. Therefore, in order to clarify the technology of Biosolvent application, a concentration close to it was used in next studies.

The leaching ability of using the Biosolvent solution 1:10, by spraying the soil, before pouring water, was clarified in a special experiment on washing soils in growing vessels.
According to the analysis of the filtrate (taking into account the volumes of the obtained filtrate), the total mass of ions, $\mathrm{HCO}_{3}$, $\mathrm{SO}_{4}, \mathrm{Ca}$ and $\mathrm{Mg}$ removed from the soil, in the variant with Biosolvent, was higher than in the control, by 52, 26, 39 and 15 $\%$.

At the same time, the bulk of the washed salts were nontoxic (sparingly soluble) compounds, the leaching of which was higher than in the control: $\mathrm{Ca}\left(\mathrm{HCO}_{3}\right)_{2}$ - by $53 \%, \mathrm{CaSO}_{4}-$ by $38 \%$, and toxic $\mathrm{MgSO}_{4}$ - by $42 \%$.

In the field, experiments on washing saline soils were carried out in the following variants: control, - conventional washing by cells (checks) and experience, - the same washing with preliminary treatment of the soil inside the checks with the Biosolvent preparation, diluted with water in a ratio of 1:10. Supply of water $2000 \mathrm{~m} 3$ / ha, preparation consumption 10 1/ha.

Some results of washing in the field are shown in Table 4 and Figure 2. It follows from the table that during washing, Biosolvent enhances the leaching of salts, both in the $0-30 \mathrm{~cm}$ layer and in the 0-70 cm layer, respectively: chlorine - in 2, 0 and 2.6 times; for sulfates - 1.7 and 1.3 times; calcium - in 2.6 and 1.6 times; sodium - in 1.3 and 1.5 times. Figure 2 also illustrates the improved leaching efficiency of salts (TDS and chlorine ions) in the soil profile, especially down to a depth of $70 \mathrm{~cm}$.

\begin{tabular}{|c|c|c|c|c|c|c|c|}
\hline \multirow[b]{2}{*}{ Ions } & \multirow[b]{2}{*}{$\begin{array}{l}\text { Variants, } \\
\text { indicators }\end{array}$} & \multicolumn{3}{|c|}{ Layer 0-30 cm } & \multicolumn{3}{|c|}{ Layer 0-70 cm } \\
\hline & & Control & Experiment & $\begin{array}{c}\text { Experiment / } \\
\text { Control, number of } \\
\text { times }\end{array}$ & Control & Experiment & $\begin{array}{c}\text { Washout } \\
\text { difference } \\
\text { experiment- } \\
\text { control } \\
\end{array}$ \\
\hline \multirow{3}{*}{$\mathrm{Cl}^{\prime}$} & Before leaching & 0,031 & 0,04 & & 0,033 & 0,037 & \\
\hline & After leaching & 0,02 & 0,012 & & 0,025 & 0,014 & \\
\hline & Removed \% & 35,5 & $\mathbf{7 0 , 0}$ & 2,0 & 24,2 & 62,2 & 2,6 \\
\hline \multirow{3}{*}{$\mathrm{SO}_{4}$} & Before leaching & 0,466 & 0,451 & & 0,538 & 0,481 & \\
\hline & After leaching & 0,352 & 0,259 & & 0,382 & 0,301 & \\
\hline & Removed \% & 24,5 & 42,6 & 1,7 & 29,0 & 37,4 & 1,3 \\
\hline \multirow{3}{*}{ Ca.. } & Before leaching & 0,086 & 0,13 & & 0,105 & 0,142 & \\
\hline & After leaching & 0,066 & 0,051 & & 0,064 & 0,054 & \\
\hline & Removed \% & 23,3 & 60,8 & 2,6 & 39,0 & 62,0 & 1,6 \\
\hline \multirow{3}{*}{ Mg.. } & Before leaching & 0,052 & 0,022 & & 0,057 & 0,024 & \\
\hline & After leaching & 0,041 & 0,034 & & 0,048 & 0,037 & \\
\hline & Removed \% & 21,2 & $-54,5$ & & 15,8 & $-54,2$ & \\
\hline \multirow{3}{*}{$\mathrm{Na}^{\prime}$} & Before leaching & 0,068 & 0,069 & & 0,071 & 0,071 & \\
\hline & After leaching & 0,031 & 0,02 & & 0,045 & 0,031 & \\
\hline & Removed \% & 54,4 & 71,0 & 1,3 & 36,6 & 56,3 & 1,5 \\
\hline \multirow{3}{*}{ K } & Before leaching & 0,018 & 0,021 & & 0,016 & 0,017 & \\
\hline & After leaching & 0,015 & 0,012 & & 0,014 & 0,01 & \\
\hline & Removed \% & 16,7 & 42,9 & 2,6 & 12,5 & 41,2 & 3,3 \\
\hline
\end{tabular}

Table 4: Comparison of changes of the content of ions in saline soil under the influence of leaching, incl. using of Biosolvent (field experiment, average from 5 control points in each option). 
The effectiveness of the effect of Biosolvent on desalinization of the soil profile is shown in Figure 2.
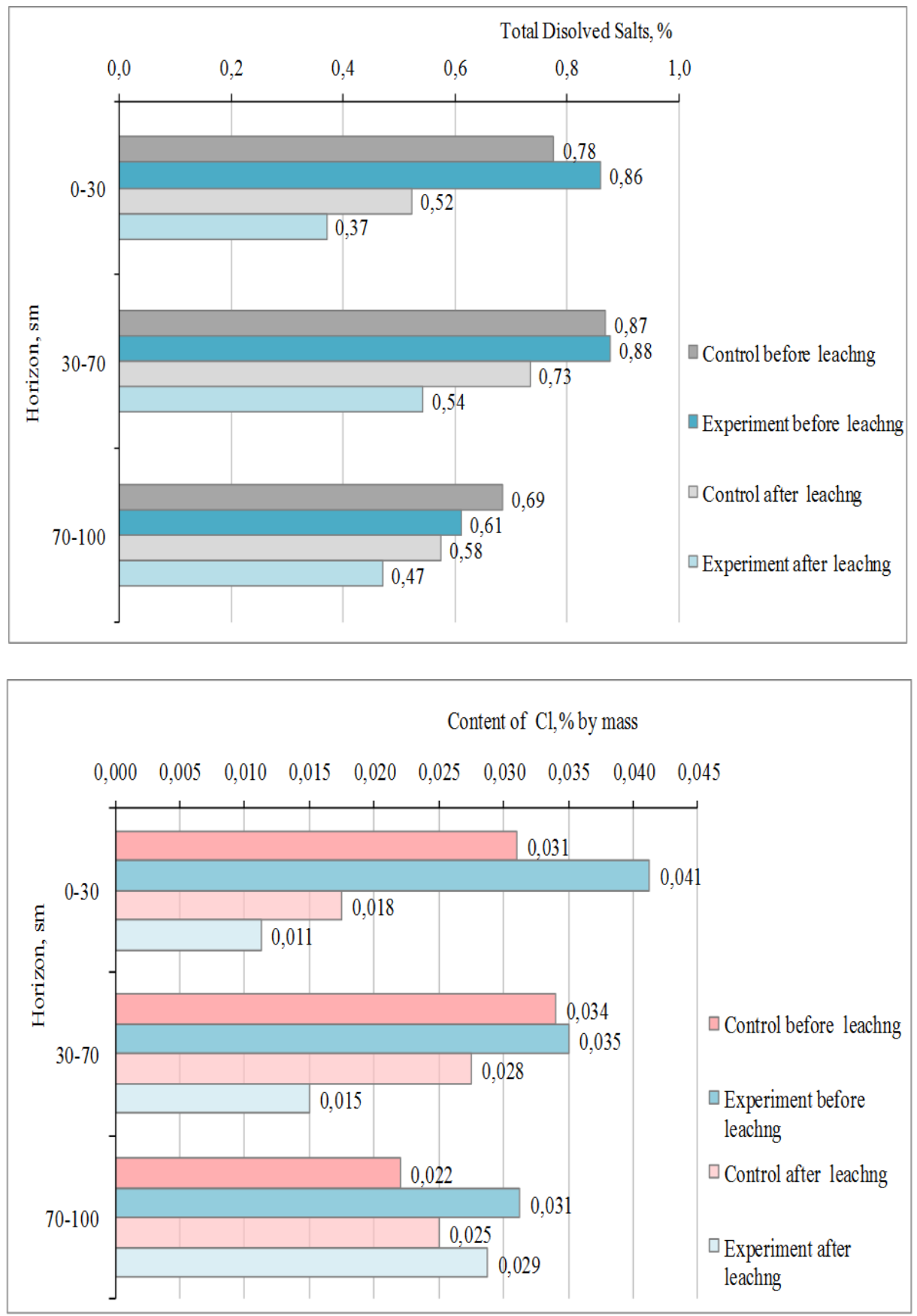

Figure 2: Comparison of changes in the content of solid residue and chlorine ion in the soil profile (average of 5 points for each option).

The data presented in this article (and previously published research materials $[\mathbf{1 0}, \mathbf{1 1}]$ ) show the effectiveness of Biosolvent application in winter-spring soil leaching from salts. Additional leaching of more than $40 \%$ of salts from the soil, due to the use of the preparation, saves $40 \%$ of water, respectively (2000 m3 / ha).
The calculated water volume of for leaching moderately saline soils is $4000-5000 \mathrm{~m} 3 / \mathrm{ha}$, and, in this case, the saving of irrigation water can be $2000 \mathrm{~m} 3 / \mathrm{ha}$. Chlorine leaching after soil treatment with the preparation more than doubles (Table 3). This means that in soils containing a large amount of chlorine ion, the volume of water saved will reach $50 \%$ (more than $2500 \mathrm{~m} 3 / \mathrm{ha}$ ). 
The results of field experiments to reduce soil salinity during vegetation irrigation, by pre-irrigation treatment of the surface of irrigation furrows with a Biosolvent solution (at the rate of 61 / ha of), are shown in Table 5 and Figures 3-5.
The effects, in the form of a significant decreasing of salts in the $0-70 \mathrm{~cm}$ layer, were obtained immediately after the first irrigation (Figure 3). During the first irrigation, in the variant with the use of the Biosolvent preparation, the percentage of leaching of all ions (except for $\mathrm{HCO}_{3}$ ) was higher than at the control variant.

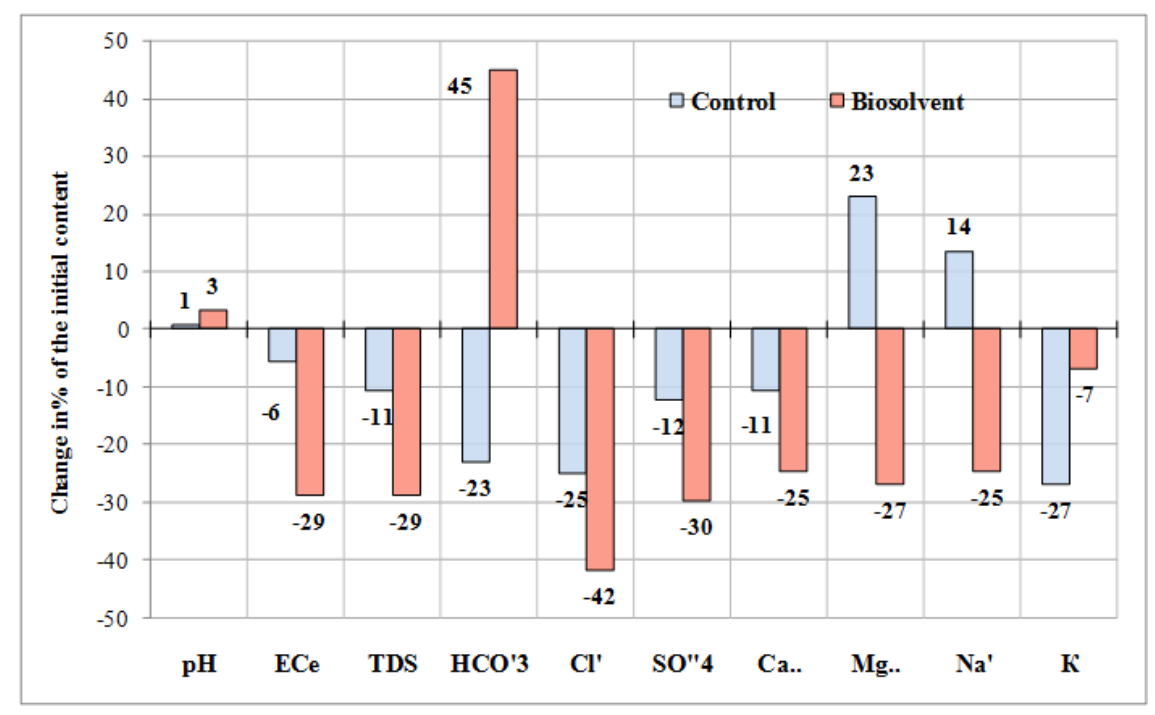

Figure 3: Comparison of leaching of ions from the soil layer $0-70 \mathrm{~cm}$ (percentage of initial content) with conventional watering and furrow surface spraying by solution of Biosolvent 1:10.

In relation to the initial content, the changing was: Total Dissolved Salts (TDS) - 29\% (11\%, in the control, the difference is $18 \%$ ); $\mathrm{Cl}^{\prime}-42 \%$ (25\% on the control, the difference is $7 \%$ ); $\mathrm{Ca}$ $-25 \%$ ( $12 \%$ on the control, the difference is $13 \%)$. The valuable element potassium (K) was leached less: $7 \%$ in the variant with Biosolvent and $23 \%$ in the control variant (difference $+16 \%$ ).
The effect of the Biosolvent preparation on the reduction of soil salinity during the growing season can be seen from a comparison of the soil salinity profiles shown in Figure 4. Soil profiles at characteristic points illustrate that the preparation reduces soil salinity in soil layers $0-30 \mathrm{~cm}$ and $30-70 \mathrm{~cm}$, and in the layer $70-100 \mathrm{~cm}$, the differences between the compared variants are less significant.
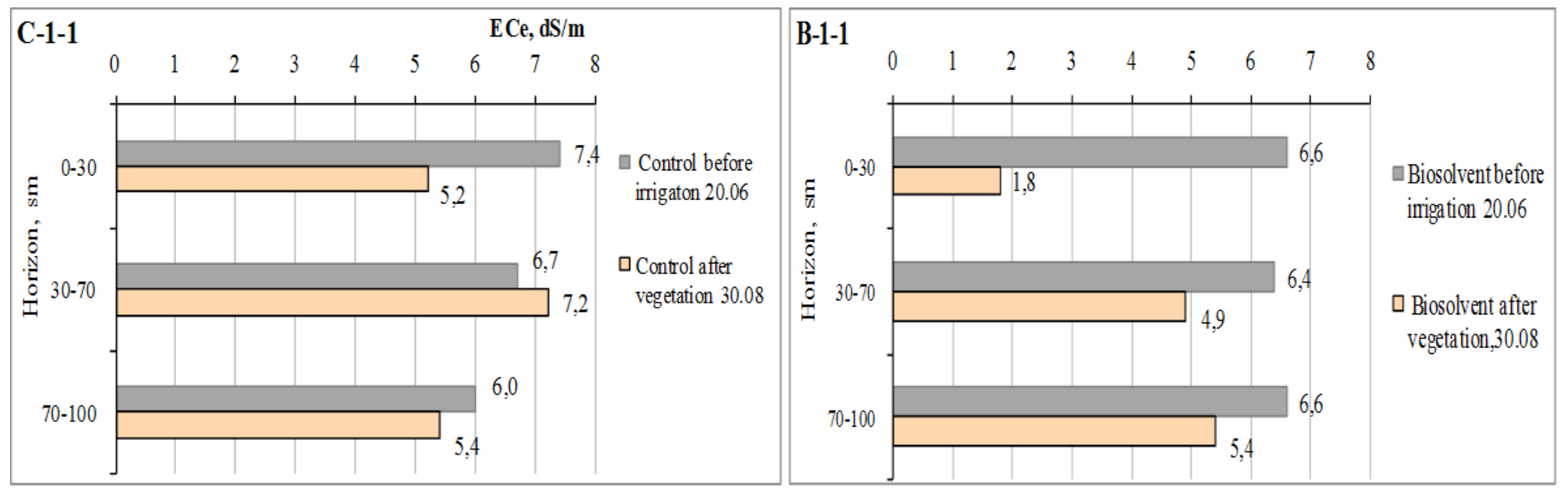

Figure 4: Comparison of the soil salinity profile at characteristic (comparable) points of the studied options.

Changes in the chemical composition of the soil (average from 5 observation points) for the options: "control" - conventional irrigation, without treatment, and "experience"
- irrigation along furrows, pretreated with a solution of Biosolvent, are shown in Table 5. 


\begin{tabular}{|c|c|c|c|c|c|c|c|c|c|c|}
\hline \multirow{2}{*}{ Experimental options } & \multirow{2}{*}{ Date } & \multirow{2}{*}{ pH } & \multirow{2}{*}{$\begin{array}{c}\text { TDS } \\
\%\end{array}$} & \multicolumn{7}{|c|}{ Soluble ions content, \% } \\
\hline & & & & $\mathrm{HCO}_{3}^{\prime}$ & $\mathrm{Cl}^{\prime}$ & $\mathrm{SO}_{4}^{\prime \prime}$ & $\mathrm{Ca} \cdot$ & $M g$ & $\mathbf{N a}^{\prime}$ & $\mathbf{K}$ \\
\hline \multicolumn{11}{|c|}{ Soil layer $0-30 \mathrm{~cm}$} \\
\hline \multirow{4}{*}{ Control, Farmer Practice } & 20.06 & 7,8 & 0,71 & 0,011 & 0,021 & 0,483 & 0,118 & 0,043 & 0,044 & 0,011 \\
\hline & 29.06. & 7,7 & 0,64 & 0,011 & 0,037 & 0,394 & 0,100 & 0,031 & 0,056 & 0,010 \\
\hline & 30.08 . & 7,7 & 0,43 & 0,010 & 0,010 & 0,296 & 0,082 & 0,021 & 0,028 & 0,006 \\
\hline & Average & 7,7 & 0,61 & 0,011 & 0,028 & 0,392 & 0,100 & 0,031 & 0,048 & 0,009 \\
\hline \multirow{4}{*}{$\begin{array}{l}\text { Experience, Spraying } \\
\text { furrows before irrigation }\end{array}$} & 20.06. & 7,7 & 0,48 & 0,009 & 0,014 & 0,326 & 0,088 & 0,020 & 0,025 & 0,006 \\
\hline & 29.06. & 7,4 & 0,23 & 0,012 & 0,010 & 0,148 & 0,037 & 0,013 & 0,019 & 0,005 \\
\hline & 30.08 . & 7,8 & 0,32 & 0,012 & 0,008 & 0,227 & 0,058 & 0,024 & 0,012 & 0,002 \\
\hline & Average & 7,5 & 0,30 & 0,011 & 0,011 & 0,199 & 0,051 & 0,016 & 0,019 & 0,005 \\
\hline $\begin{array}{c}\text { Variants ratio: control / } \\
\text { experience }\end{array}$ & Average & 1,0 & 2,0 & 1,0 & 2,5 & 2,0 & 2,0 & 1,9 & 2,5 & 1,8 \\
\hline \multicolumn{11}{|c|}{ Soil layer 0-70 cm } \\
\hline \multirow{4}{*}{ Control, Farmer Practice } & 20.06. & 7,8 & 0,69 & 0,011 & 0,020 & 0,469 & 0,110 & 0,042 & 0,045 & 0,011 \\
\hline & 29.06. & 7,7 & 0,63 & 0,010 & 0,038 & 0,400 & 0,101 & 0,032 & 0,051 & 0,009 \\
\hline & 30.08. & 7,6 & 0,55 & 0,010 & 0,013 & 0,387 & 0,104 & 0,029 & 0,034 & 0,006 \\
\hline & Average & 7,7 & 0,63 & 0,010 & 0,029 & 0,411 & 0,104 & 0,034 & 0,046 & 0,009 \\
\hline \multirow{4}{*}{$\begin{array}{l}\text { Experience, Spraying } \\
\text { furrows before irrigation }\end{array}$} & 20.06 & 7,7 & 0,53 & 0,008 & 0,014 & 0,362 & 0,098 & 0,023 & 0,027 & 0,006 \\
\hline & 29.06. & 7,5 & 0,23 & 0,011 & 0,010 & 0,148 & 0,037 & 0,012 & 0,020 & 0,005 \\
\hline & 30.08 & 7,7 & 0,45 & 0,011 & 0,010 & 0,323 & 0,086 & 0,030 & 0,022 & 0,002 \\
\hline & Average & 7,5 & 0,33 & 0,011 & 0,011 & 0,226 & 0,059 & 0,018 & 0,022 & 0,005 \\
\hline $\begin{array}{c}\text { Variants ratio: control / } \\
\text { experience }\end{array}$ & Average & 1,0 & 1,9 & 0,9 & 2,6 & 1,8 & 1,8 & 1,9 & 2,1 & 1,8 \\
\hline
\end{tabular}

Table 5: Comparison of the dynamics of the content of ions in the soil in the experiment with the treatment of furrows with Biosolvent before irrigation.

The table shows that under the influence of treatment, there was an increase in the leaching of salts from the soil, compared with conventional irrigation. At the same time, leaching increased (respectively, in soil layers $0-30 \mathrm{~cm}$ and 0-70 cm): for TDS, - 2.0 and 1.9 times, for chlorine ion,- 2.5-2.6 times, for sulfates and calcium, - 2.0-1.8 times, for magnesium - 1.9 times, for sodium 2.5 and 2.1 times.

(Figure 5) shows the dynamics of soil salinity during the growing season with conventional irrigation and with irrigation, with preliminary processing of the furrow surface. It can be seen from the figure that under the influence of the treatment of furrows with the preparation, during watering, the content of salts in the soil decreases, and also that this phenomenon is prolonged and persists until the end of the growing season ${ }^{1}$.

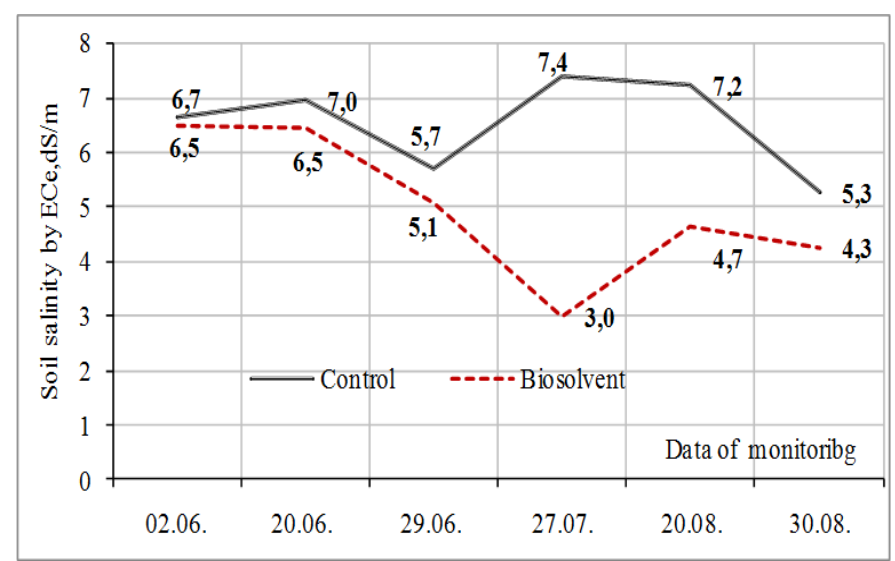

Figure 5: Influence of furrow treatment with Biosolvent on the salt regime of the irrigated field in a layer of 0-70 cm.Figures 4 and 5 show that the effects of salt leaching, achieved after the

first irrigation, persist until the end of the growing season.

In the variant with the use of the preparation, the soil salinity in autumn was $1 \mathrm{dS} / \mathrm{m}$ less than in the control. Consequently, the use of the drug during the growing season can contribute not only to an increase in yield $(7.5 \mathrm{c} / \mathrm{ha})$, but also to save more than 1000 $\mathrm{m} 3 /$ ha of water, with subsequent leaching of land during the nongrowing season [1]. 
${ }^{1}$ Experimental leaching established water consumption to reduce salinity: $1000 \mathrm{~m} 3$ / ha per $1 \mathrm{dS} / \mathrm{m}$, with an average degree of soil salinity [6].

\section{Conclusion}

1. Laboratory experiments on physical modeling of the leaching of salts from highly saline soils on bulk columns at leaching rates from 500 to $1000 \mathrm{~m} 3 /$ ha revealed that adding the Biosolvent preparation to water (up to a concentration of $2 \%$ ) provides sufficient leaching of salts. It was also found that a $10 \%$ solution of the preparation has a high leaching capacity.

2. Special experiments in vegetation vessels established the leaching capacity of Biosolvent when the soil was sprayed with a solution of the preparation with water (1:10) before irrigation. This technology increases the leaching of ions, $\mathrm{HCO} 3, \mathrm{SO}^{4} 4, \mathrm{Ca}$ and $\mathrm{Mg}$, respectively by 52, 26, 49 and $15 \%$. The amount of calcium and magnesium compounds removed by the filtrates was $40-50 \%$ higher than in the control.

3. The technology of application of the Biosolvent preparation by spraying saline soils before leaching was tested in the field. Quantitative indicators of the effectiveness of this drug and its consumption have been established. At a drug consumption of $10 \mathrm{l} / \mathrm{ha}$, for soil cultivation inside the leaching checks, the salt leaching efficiency increases by 35

... 42\%, which allows saving up to $2000 \mathrm{~m} 3 /$ ha of scarce water.

4. Field experiments have shown that when the preparation is applied to irrigated furrows of saline soils before the vegetative irrigation of cotton, the removal of salts from the root layer is $18-25 \%$ higher than during conventional irrigation. Depth desalinization drug exposure greater than 70 $\mathrm{cm}$, and the duration of its effect persists from the time of irrigation, to the end of the growing season. As a result of creating more favorable conditions, an additional cotton crop was obtained $-7.5 \mathrm{c} / \mathrm{ha}$.

5. Depth desalinization drug exposure greater than $70 \mathrm{~cm}$, and the duration of its effect persists from the time of irrigation, to the end of the growing season.

6. The use of the Biosolvent preparation as an ameliorant of saline lands is a means for managing the water-salt regime of an irrigated field and allows (at relatively low financial costs) to save water during land leaching: $2000 \mathrm{~m} 3 / \mathrm{ha}$ - this year, and more than $1000 \mathrm{~m} 3 / \mathrm{ha}$, in the next year, due to a decrease in the seasonal accumulation of salts in the soil.

7. The practical significance of the development is that the use of this drug is available to farmers.

\section{References}

1. Ramazanov AR, YakubovKhI (1988) Flushing and water charging irrigation.

2. Bresler E, McNeill BL, Carter DL (1987) Salt marshes and salt licks.

3. Bernstein L (1975) Effects of salinity and sodicity on plant growth.AnnuRevPhytopathol295-312.

4. Mass EV, Hoffman GJ (1977) Crop salt tolerance - current assessment.J Irrig Drain DivProc Am Soc Civil Eng115134.

5. Davis JG, Whiting D(2005)Choosing a Soil Amendment.

6. ShirokovaYuI, Paluashova G, Razhabov K, Koshekov R (2007) Efficiency of flush irrigation 23-28.

7. Sper Sal 35 Soil Conditioner [Electronic resource].

8. Spersal R SL-Plant growth support (soil conditioner) [Electronic resource].

9. DeSaltus - a polymaleic acid formulation that removes sodium from the rootzone [Electronic resource].

10. Khudoynazarov IA,Normakhamatov N, ShirokovaYuI, Filatova A,Turaev A et al. (2018) Study of leaching of saline soils using the polymer composition "Biosolvent". Scientific journalUniversum: Chemistry and Biology 6:2631.

11. Khudoynazarov IA, Sadiev FF (2017) Influence of the preparation "Biosolvent" on the indicators of soil fertility during leaching. Sustainable land management in the face of climate change. Collection of articles of the republican scientific and practical seminar April 22 - International Earth Day. Tashkent 373-376.

12. Shirokova Yu, Paluashova G, Sadiev F, Sharafutdinova N(2017)“'Influence of Biological Preparations on Melioration of Saline Soils: Case Study from Uzbekistan presentation in the session "Central Asia I". Conference Tropentag, Bonn, Germany 20 - 22 September.

13. Khudoynazarov IA, Turaev AS, Paluashova GK, SharafutdinovaNSh, ShirokovaYuI et al. (2018) Innovative solutions to reduce soil salinity with the help of a domestic product - a desalination agent. Rep Scientific and practical conference dedicated to the 100th anniversary of the National University of Uzbekistan named after MirzoUlugbek "Soil, climate, fertilizer and harvest: current problems and prospects", December 5, Moscow 298-301.

14. Sadiev FF, Ramazanov AR (2020) The method of reclamation of saline and gypsum soils of the Hungry Steppe with the use of biological and chemical preparations. XV International Scientific and Practical Conference "Agricultural Science for Agriculture" (March 12-13), Barnaul: RIO Altai State Agrarian University, Book 1: 399401.

Citation: Shirokova Y, Paluashova G, Sadiev F (2020) Results of Testing the Leaching Ability of the Biosolvent Preparation on Salted Soils of the Middle Current of the Syrdarya River. Adv in Agri, Horti and Ento: AAHE-128. 